\title{
PREDIKSI NILAI FIXED CARBON SEBAGAI VARIABEL DALAM KUALITAS BATUBARA DENGAN METODA ORDINARY POINT KRIGING MENGGUNAKAN APLIKASI R
}

\section{FIXED CARBON ESTIMATION AS VARIABLES IN COAL QUALITY BY MEANS ORDINARY POINT KRIGING METHOD USING R PROGRAMMING}

\author{
Budi Nurani Ruchjana1, Annisa Nur Falah', Endang Rusyaman', dan Nur Hamid ${ }^{2}$ \\ ${ }^{1}$ Departemen Matematika, Fakultas Matematika dan IImu Pengetahuan Alam \\ Universitas Padjadjaran \\ ${ }^{2}$ Departemen Geologi, Fakultas Teknik Geologi Sekolah Tinggi Teknologi Mineral Indonesia \\ budi.nurani@unpad.ac.id
}

\begin{abstract}
ABSTRAK
Data spasial adalah data yang diperoleh dari hasil pengukuran yang berisi informasi tentang lokasi, umumnya berdasarkan peta yang berisikan interpretasi dan proyeksi seluruh fenomena yang berada di bumi. Metoda Ordinary Point Kriging adalah salah satu metoda yang dapat digunakan untuk analisis data spasial dalam Geostatistika yang digunakan untuk mengestimasi nilai dari sebuah titik di lokasi tidak tersampel sebagai kombinasi linear dari nilai contoh yang terdapat di sekitar titik yang akan diestimasi. Bobot kriging diperoleh dari hasil variansi estimasi minimum menggunakan semivariogram sebagai input. Untuk studi kasus penerapan Metoda Ordinary Point Kriging, digunakan data karbon tertambat (fixed carbon) sebagai variabel kualitas batubara dari hasil uji laboratorium di PT Bumi Merapi yang menunjukkan bahwa kualitas batubara berada dalam peringkat Lignite. Fixed carbon menyatakan banyaknya karbon yang terdapat dalam material sisa setelah zat terbang (volatile matter) dihilangkan. Nilai fixed carbon sangat mempengaruhi kualitas suatu batubara, karena semakin tinggi nilai fixed carbon maka kualitas batubara semakin meningkat. Proses perhitungan estimasi fixed carbon di lokasi yang tidak tersampel menggunakan Metoda Ordinary Point Kriging dapat diselesaikan dengan package gstat pada Aplikasi $\mathrm{R}$, dan memberikan nilai hasil estimasi mendekati nilai data sampel. Oleh karena itu, perhitungan Metoda Ordinary Point Kriging menggunakan aplikasi R memberikan perhitungan yang lebih mudah, cepat, dan akurat.
\end{abstract}

Kata kunci: Ordinary Point Kriging, Fixed Carbon, Aplikasi R, estimasi, lokasi yang tidak tersampel

\section{ABSTRACT}

Spatial data is a type of measurement data with location information, based on maps which contain interpretations and projections of all earth phenomena. Ordinary Point Kriging method can be used for spatial data analysis in Geostatistics. It is used to estimate the value of a point in an unobserved location as a linear combination of sample values found around the point to be estimated. Kriging quality is obtained from the results of the minimum estimation variance using semivariogram as input. As a case study, fixed carbon data are used as a variable of coal quality from the results of laboratory test at PT Bumi Merapi which indicates Lignite. Fixed carbon represents the amount of carbon in residual material after the volatile matter is removed. Coal quality increases as increasing Fixed Carbon. Fixed carbon estimation in unobserved locations using the Ordinary Point Kriging Method can be solved by package gstat on $R$ programming, resulting in an estimated values close to the value of the sampled data. Therefore, calculations on Ordinary Point Kriging Method using the $R$ programming provide easier, faster, and more accurate estimation.

Keywords: Ordinary Point Kriging, Fixed Carbon, R Programming, estimation, unobserved location 


\section{PENDAHULUAN}

Geostatistika merupakan perpaduan ilmu pertambangan, geologi, matematika, dan statistika yang awalnya dikembangkan dalam industri mineral untuk menaksir cadangan-cadangan mineral yang ada di bumi (Cressie, 1993). Dalam Geostatistika sering kali digunakan Pengali Lagrange untuk menentukan nilai maksimum atau nilai minimum dari suatu fungsi yang memiliki kendala (Varberg, et. al., 2007). Kegunaan Pengali Lagrange pada bidang Geostatistika tersebut salah satunya digunakan untuk meminimumkan variansi estimasi pada Metoda estimasi di lokasi tidak tersampel, atau yang dikenal dengan Metoda Kriging (Olea, 1999). Metoda Kriging terdiri dari beberapa macam, yaitu: Metoda Ordinary Point Kriging dan Metoda Ordinary Block Kriging yang mengasumsikan rata-rata tidak diketahui, Metoda Simple Kriging yang mengasumsikan rata-rata diketahui dan konstan, Metoda Universal Kriging yang mengasumsikan rata-rata diketahui dan tidak konstan, dan Metoda Co-Kriging yang merupakan gabungan dari dua atau lebih Metoda Kriging (Ruchjana, dkk. 2017). Metoda Ordinary Point Kriging telah digunakan dalam estimasi polutan pada dataran banjir sungai Meuse (Falah, et al., 2017a). Hasil estimasi dengan Metoda Ordinary Point Kriging telah dibuat konturnya dengan proyeksi ke google map (Gunawan, et al., 2016). Estimasi polutan tersebut dikembangkan dengan menggunakan Metoda Universal Kriging (Falah, et al., 2017b). Seiring dengan perkembangan ilmu pengetahuan dan teknologi, pada penelitian ini dibahas kegunaan Metoda Ordinary Point Kriging pada tambang batubara (coal mine). Para peneliti telah menggunakan Metoda Kriging pada tambang batubara, salah satunya digunakan untuk manajemen risiko pada industri batubara (Srivastava, 2013), kemudian digunakan untuk estimasi kualitas batubara (Ertunc, 2013). Selain itu Metoda Kriging digunakan pula untuk mengestimasi ketebalan lapisan batubara (Youkuo, et al., 2015) dan untuk mengestimasi kuat geser batuan pada tambang batubara (Hamid, 2017).

Batubara terbentuk dari bahan organik seperti jejak kulit pohon, daun, akar, struktur kayu, spora, polen, damar, dan lain-lain. Proses pembusukan bahan organik tersebut menyebabkan perubahan baik sifat fisik maupun kimia pada waktu sebelum atau sesudah tertutup oleh endapan lainnya (Tirasonjaya dalam www.geologinesia.com, 2016).

Kualitas dari setiap endapan batubara ditentukan oleh suhu dan tekanan serta lamanya waktu pembentukan. Batubara terbentuk melalui dua tahap mulai dari proses penggambutan yang merupakan tahap biokimia, dan dilanjutkan dengan proses pembatubaraan yang merupakan tahap geokimia. Proses pembatubaraan terjadi pada rawa yang selalu tergenang air (kisaran kedalaman 0,5 - 10 meter) dengan kondisi reduksi dan sistem pengeringan yang buruk (www.geologinesia. com, 2016).

Indonesia merupakan negara yang kaya dengan sumber daya alam, termasuk batubara. Menurut data Badan Geologi, cadangan batubara saat ini mencapai 39,89 miliar ton. Namun cadangan tersebut masih tergolong kecil di tingkat dunia karena masih di kisaran rata-rata 3\%-4\% cadangan dunia (Kementerian ESDM dalam https://www.cnbcindonesia.com, 2019). Batubara dalam suatu tambang terbuka umumnya mencakup wilayah yang cukup luas dengan karakteristik spasial yang homogen. Cadangan batubara di Indonesia pada umumnya termasuk batubara peringkat rendah dengan kadar air total (air bawaan dan air total) yang mencapai 40\%. (Arisandy, dkk., 2017).

Berbagai variabel yang memengaruhi kualitas batubara diantaranya adalah Zat terbang (Volatile Matter), Karbon Tertambat (Fixed Carbon), Kandungan Abu (Ash Content), Nilai Kalori (Calorific Value), dan kandungan sulfur total (Total Sulphur) (Schweinfurth, 2009). Variabel tersebut 
diperoleh dari hasil analisis batubara dalam basis ADB (Air Dried Basis). Pada kondisi ADB ini Free Moisture tidak diikutsertakan.

Volatile matter adalah senyawa organik atau anorganik yang hilang saat batubara yang dihilangkan kandungan airnya dipanaskan pada suhu tinggi dalam waktu tertentu. Sedangkan Calorific Value merupakan panas yang dihasilkan, apabila batubara tersebut dibakar. Besaran nilai kalor batubara sangat ditentukan oleh jenis batubara (Arisandy, dkk., 2017). Fixed carbon digunakan sebagai indeks hasil kokas dari batubara pada waktu dikarbonisasikan, atau sebagai suatu ukuran material padat yang dapat dibakar di dalam peralatan pembakaran batubara setelah fraksi zat mudah menguap dihilangkan. Apabila ash telah dikoreksi, maka kandungan Fixed Carbon dapat dipakai sebagai indeks perankingan batubara dan parameter untuk mengklasifikasikan batubara.

Untuk menentukan kualitas batubara dilakukan analisis kimia pada batubara yang diantaranya berupa analisis proksimat dan analisis ultimat. Analisis proksimat dilakukan untuk menentukan moisture, volatile matter, fixed carbon dan ash, sedangkan analisis ultimat dilakukan untuk menentukan kandungan unsur kimia pada batubara seperti: karbon, hidrogen, oksigen, nitrogen, sulfur, unsur tambahan dan juga unsur jarang (www.geologinesia.com, 2016).

Uji parameter batubara dapat menggunakan analisis dalam berbagai basis analisis yang terdiri dari DMMF (Dried Mineral Matter Free basis), DAF (Dry Ash Free basis), Db (Dry Basis), AD (Air Dried Basis), dan AR (As Received basis) (Arisandy, dkk., 2017).

Peringkat (rank) dan derajat batubara ditentukan berdasarkan proses perubahan atau genesa batubara. Peringkat batubara meningkat seiring proses pembentukan batubara, dimana peningkatan peringkat ini akan meningkatkan kandungan fixed carbon. Peringkat batubara secara umum mulai dari peringkat rendah ke peringkat tertinggi adalah lignite, batubara subbituminous, batubara bituminous dan anthracite. Secara umum berdasarkan kandungan carbon dan oksigen, klasifikasi batubara dapat diuraikan sebagai berikut:

- Gambut (Peat), yang merupakan cikal bakal batubara, Carbon $=60 \%-64 \%$ (dmmf), Oxygen $=30 \%(\mathrm{dmmf})$

- Lignite atau batubara muda, Carbon = $64 \%-75 \%$ (dmmf), Oxygen $=20 \%-$ $25 \%$ (dmmf)

- Sub-bituminous, Carbon $=75 \%-83 \%$ (dmmf), Oxygen $=10 \%-20 \%(\mathrm{dmmf})$

- Bituminous, Carbon $=83 \%-90 \%$ (dmmf), Oxygen $=5 \%-15 \%(\mathrm{dmmf})$

- Semi-anthracite, Carbon $=90 \%-93 \%$ (dmmf), Oxygen $=2 \%-4 \%(\mathrm{dmmf})$

- Anthracite, Carbon = > 93\% (www.geologinesia.com, 2016).

Batubara juga dapat diklasifikasikan berdasarkan Gross Calorific Value (Gross CV) dan fixed carbon seperti yang disajikan pada Gambar 3 (Schweinfurth, 2009).

Berdasarkan Gambar 3, tampak bahwa fixed carbon merupakan salah satu variabel yang sangat mempengaruhi kualitas batubara dan perlu diestimasi untuk lokasi yang tidak tersampel dalam suatu tambang batubara. Salah satu Metoda yang dapat digunakan untuk mengestimasi variabel-variabel yang memengaruhi kualitas batubara tersebut adalah Metoda Ordinary Point Kriging (Ertunc, et. al., 2013). Dalam penelitian ini diterapkan Metoda Ordinary Point Kriging untuk estimasi fixed carbon dalam tambang batubara melalui data hasil uji laboratorium di PT Bumi Merapi Barat Lahat Sumatera Selatan.

Perangkat lunak yang dapat digunakan dalam proses estimasi di lokasi tidak tersampel adalah Aplikasi $\mathrm{R}$ yang merupakan software open source dan menyediakan package gstat untuk estimasi dengan Metoda Ordinary Point Kriging (Bivand, et al., 2013). 


\section{MAKALAH ILMIAH}

Penelitian mengenai penerapan Metoda Ordinary Point Kriging pada kasus tambang batubara telah banyak dilakukan. Akan tetapi, belum banyak yang membahas mengenai estimasi kualitas batubara menggunakan Metoda Ordinary Point Kriging dengan perhitungan menggunakan Aplikasi R. Oleh karena itu, dalam penelitian ini dilakukan estimasi fixed carbon dengan Metoda Ordinary Point Kriging menggunakan Aplikasi R.

\section{TINJAUAN PUSTAKA}

\section{Semivariogram}

Semivariogram adalah ukuran korelasi spasial dari observasi di lokasi-lokasi pengamatan yang berjarak $h$ satuan jarak. Taksiran semivariogram eksperimental pada jarak $h$, dapat dituliskan sebagai berikut (Youkuo, et. al., 2015):

$\hat{\gamma}(h)=\frac{1}{2 N(h)} \sum_{i=1}^{N(h)}\left[Z\left(x_{i}+h\right)-Z\left(x_{i}\right)\right]^{2}$

dengan:

$\hat{\gamma}(h) \quad$ : nilai semivariogram pada jarak $h$

$Z\left(x_{i}\right) \quad$ : nilai pengamatan di lokasi $x_{i}$

$Z\left(x_{i}+h\right)$ : nilai pengamatan di lokasi $x_{i}+h$

$N(h) \quad$ : banyaknya pasangan titik yang mempunyai jarak $h$

$h \quad$ : jarak antara 2 pengamatan

Pasangan jarak Euclidean $h$ dihitung menggunakan persamaan berikut:

$|h|=\sqrt{\left(x_{i}-x_{j}\right)^{2}+\left(y_{i}-y_{j}\right)^{2}}$

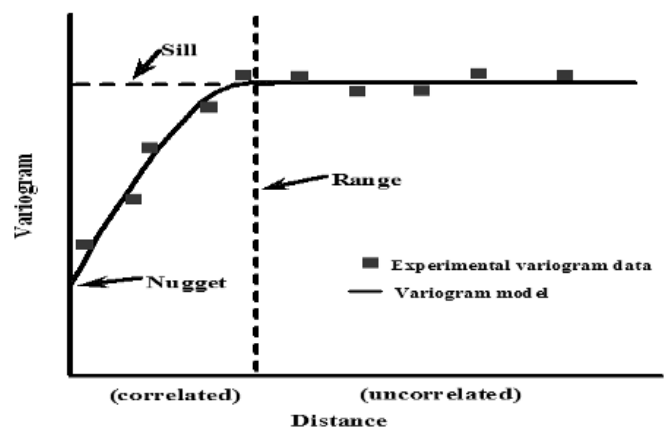

Gambar 1. Grafik Semivariogram Eksperimental

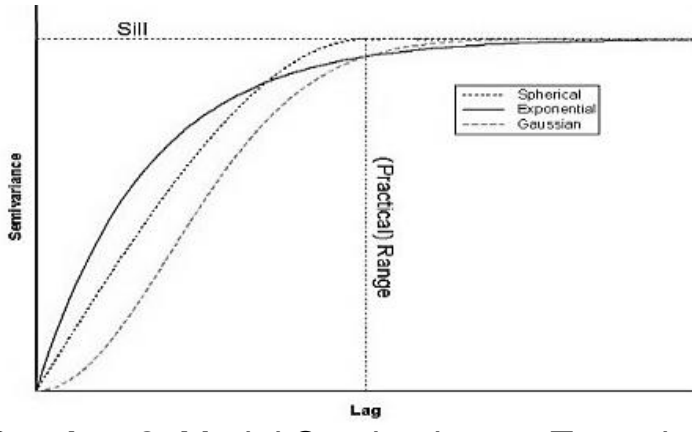

Gambar 2. Model SemivariogramTeoretis

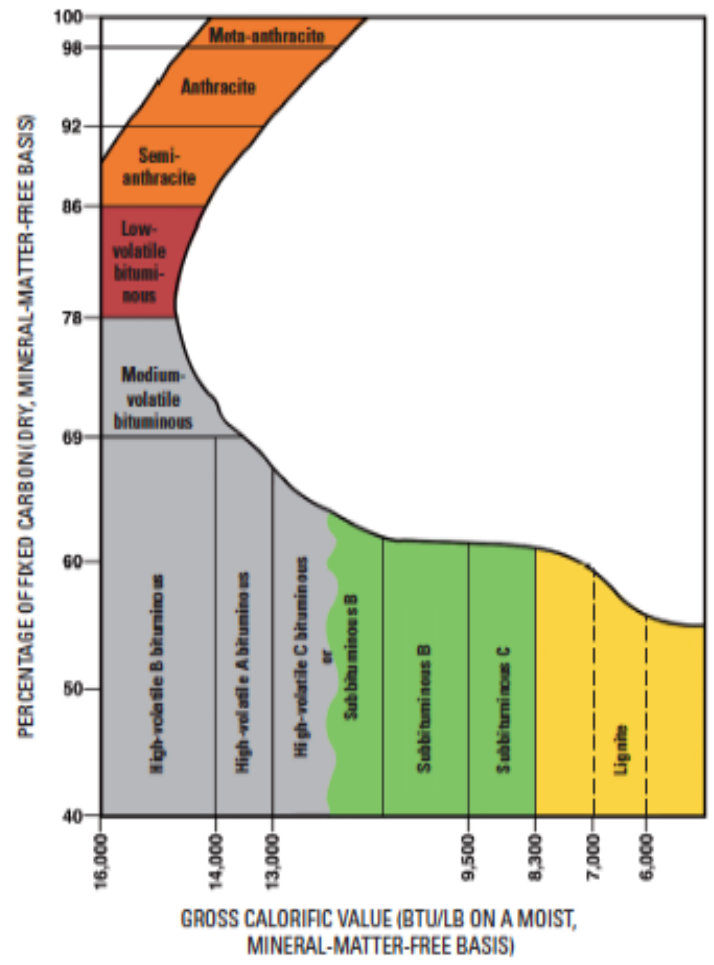

Gambar 3. Diagram Rank Batubara berdasarkan Calorific Value dan Fixed Carbon (Schweinfurth, 2009)

\section{Model Semivariogram Teoretis}

Model Semivariogram Teoretis yang paling umum digunakan ada 3, yaitu: Model Spherical, Model Gaussian dan Model Eksponensial (Youkuo, et al., 2015). Model teoretis tersebut dinyatakan sebagai berikut :

- Model Eksponensial

$$
\gamma(h)=\left\{\begin{array}{l}
c\left[1-\exp \left(\frac{-h}{a}\right)\right], \text { untuk } h \leq a \\
c \quad, \text { untuk } h>a
\end{array}\right.
$$


- Model Gaussian

$$
\gamma(h)=\left\{\begin{array}{l}
c\left[1-\exp \left(\frac{-h}{a}\right)^{2}\right], \text { untuk } h \leq a \\
c \quad, \text { untuk } h>a
\end{array}\right.
$$

- Model Spherical

$$
\gamma(h)=\left\{\begin{array}{l}
c\left[\left(\frac{3 h}{2 a}\right)-\left(\frac{h^{3}}{2 a^{3}}\right)\right], \text { untuk } h \leq a \\
c \quad, \text { untuk } h>a
\end{array}\right.
$$

Dengan menghitung error antara model semivariogram teoretis dan semivariogram eksperimental diperoleh model semivariogram terbaik, yaitu yang memiliki jumlah kuadrat error atau Sum Square Error (SSE) yang minimum. Selanjutnya parameter dari model semivariogram terbaik tersebut menjadi input dalam Metoda Ordinary Point Kriging, yaitu terdiri dari sill (variansi) dan range (daerah pengaruh). Dengan memasukkan kedua parameter tersebut, maka diperoleh bobot kriging untuk setiap lokasi yang tidak tersampel.

Plot ketiga model semivariogram teoretis yang sering digunakan tersebut disajikan pada Gambar 2. Model spherical dari titik awal sampai mencapai sill memiliki plot linear, sedangkan eksponensial berpola melengkung dan Gaussian mempunyai pola kuadratik.

\section{Metoda Ordinary Point Kriging}

Metoda Ordinary Point Kriging dapat digunakan untuk mengestimasi nilai dari sebuah titik sebagai kombinasi linier dari nilai sampel yang terdapat di sekitar titik yang akan diestimasi. Estimator kriging dapat diartikan sebagai variabel tidak bias dan mempunyai penjumlahan dari keseluruhan bobot adalah satu. Bobot inilah yang dipakai untuk mengestimasi nilai dari berbagai variabel penentu kualitas batubara.
Penaksir atau estimator Ordinary Point Kriging memiliki sifat:

- Linear

Berdasarkan Wackernagel estimator Ordinary Point Kriging untuk dua variabel yang diperoleh dari $n$ observasi data yang digunakan membentuk model linear, yaitu:

$$
Z(x)=\sum_{i=1}^{n} \lambda_{i}\left[Z\left(x_{i}\right)\right]
$$

\section{- Tak bias (unbiased)}

Berdasarkan Olea (1999) estimator Ordinary Point Kriging bersifat tak bias jika mean diasumsikan tidak diketahui dan $E\left[Z_{1}\left(x_{i}\right)-Z(x)\right]=0, \quad$ sehingga sifat estimator tak bias terpenuhi oleh Metoda Ordinary Point Kriging.

$$
\begin{aligned}
E[Z(x)-Z(x)] & =E\left[\sum_{i=1}^{n} \lambda_{i} Z\left(x_{i}\right)-Z(x)\right] \\
& =\sum_{i=1}^{n} \lambda_{i} E\left[Z_{1}\left(x_{i}\right)-Z(x)\right] \\
& =0
\end{aligned}
$$

- Variansi minimum (Best)

Pengertian best dalam hal ini adalah estimator Ordinary Point Kriging memiliki variansi minimum. Variansi estimator dari Ordinary Point Kriging dinyatakan sebagai berikut:

$$
\begin{aligned}
\sigma_{O K}^{2}= & \operatorname{Var}[Z(x)-Z(x)] \\
\sigma_{O K}^{2}= & \sum_{i=1}^{n} \sum_{j=1}^{n} \lambda_{i} \lambda_{j} \operatorname{Cov}\left[Z\left(x_{i}\right), Z\left(x_{j}\right)\right]+ \\
& \sigma^{2}-2 \sum_{i=1}^{n} \lambda_{i} \operatorname{Cov}\left[Z\left(x_{i}\right), Z(x)\right]
\end{aligned}
$$

Untuk memperoleh nilai minimum dari variansi error digunakan Metoda Pengali Lagrange dengan parameter Pengali Lagrange $\mu_{1}$ dan $\mu_{2}$, sehingga persamaan Pengali Lagrange dinyatakan sebagai berikut (Olea, 1999): 


$$
\begin{aligned}
F\left(\lambda_{i}, \mu\right)= & \sum_{i=1}^{n} \sum_{j=1}^{n} \lambda_{i} \lambda_{j} \operatorname{Cov}\left[Z\left(x_{i}\right), Z\left(x_{j}\right)\right]+\sigma^{2} \\
& -2 \sum_{i=1}^{n} \lambda_{i} \operatorname{Cov}\left[Z\left(x_{i}\right), Z(x)\right] \\
& +2 \mu\left[\sum_{i=1}^{n} \lambda_{i}-1\right]
\end{aligned}
$$

dengan menurunkan persamaan tersebut terhadap keempat variabel, akan dapat dibentuk matriks bobot kriging sebagai berikut:

$$
\left(\begin{array}{c}
\lambda_{1} \\
\lambda_{2} \\
\lambda_{3} \\
\vdots \\
\lambda_{n} \\
\mu
\end{array}\right)=\left(\begin{array}{cccccc}
C_{11} & C_{12} & C_{13} & \cdots & C_{1 n} & 1 \\
C_{21} & C_{22} & C_{23} & \cdots & C_{2 n} & 1 \\
C_{31} & C_{32} & C_{33} & \cdots & C_{3 n} & 1 \\
\vdots & \vdots & \vdots & \ddots & \vdots & \vdots \\
C_{n 1} & C_{n 2} & C_{n 3} & \cdots & C_{n n} & 1 \\
1 & 1 & 1 & 1 & 1 & 0
\end{array}\right)^{-1}\left(\begin{array}{c}
C_{10} \\
C_{20} \\
C_{30} \\
\vdots \\
C_{n 0} \\
1
\end{array}\right)
$$

dengan:

$\mathbf{C}_{n n} \quad$ : Matriks variansi kovariansi antara variabel tersampel pada lokasi $n$ dengan variabel tersampel pada lokasi $n$

$\mathbf{C}_{n 0} \quad$ : Vektor variansi kovariansi antara variabel tersampel pada lokasi $n$ dengan variabel yang akan diestimasi di lokasi tidak tersampel

$\mu \quad$ : Parameter Pengali Lagrange

Selanjutnya diperoleh persamaan variansi estimator Ordinary Point Kriging sebagai berikut:

$\sigma_{e}^{2}=\sigma^{2}-\sum_{i=1}^{n} \lambda_{i} \operatorname{Cov}\left[Z\left(x_{i}\right), Z(x)\right]-\mu$

Variansi estimator minimum tersebut biasa disebut dengan variansi estimator Ordinary Kriging, dengan demikian sifat best dimiliki oleh Metoda Ordinary Kriging.

\section{METODA PENELITIAN}

Tahapan Penggunaan Aplikasi R untuk Metoda Ordinary Point Kriging digambarkan melalui prosedur perhitungan estimasi menggunakan Metoda Ordinary Point Kriging pada Aplikasi $\mathrm{R}$ dengan langkah-langkah sebagai berikut (Bivand, 2013):

- Aktivasi package yang digunakan Package yang digunakan dalam proses perhitungan Metoda Ordinary Point Kriging adalah package gstat, package sp, package plot3D.

- Input Data

Proses input data pada Aplikasi $\mathrm{R}$ terdapat 2 cara yaitu, input data set yang berasal dari Aplikasi $\mathrm{R}$ atau input data dari file lain. Package yang dapat digunakan untuk mempermudah input data dari file lain adalah package Rcmdr.

- Periksa Kestasioneran Data

Setelah input data, data tersebut diperiksa apakah stasioner atau tidak. Jika data tersebut stasioner dan univariat maka dapat digunakan Metoda Ordinary Point Kriging.

- Menghitung Semivariogram

Menghitung nilai Semivariogram Eksperimental diperlukan untuk data univariat. Hal ini digunakan sebagai acuan untuk memilih Model Semivariogram Teoretis dengan menggunakan vgm.

- Fitting Model Semivariogram Teoretis Memilih Model Semivariogram Teoretis yang terbaik dapat dilakukan berdasarkan plot grafik dan SSE paling minimum. Fungsi untuk memilih model terbaik adalah fit.variogram.

- Estimasi dengan Metoda Ordinary Point Kriging

Model Teoretis yang terbaik dijadikan input dalam perhitungan Metoda Ordinary Point Kriging, fungsi untuk menghitung estimasi dan variansi estimasi yang minimum adalah fungsi predict. 


\section{PEMBAHASAN}

\section{Data Penelitian}

Data yang digunakan dalam penelitian ini merupakan data sekunder hasil uji laboratorium di PT Bumi Merapi yang berada di Desa Kungkilan, Kecamatan Merapi, Kabupaten Lahat, Sumatera Selatan. Peta dari lokasi penelitian tersebut dapat dilihat pada Gambar 4.

Lokasi penelitian berjarak sekitar $10 \mathrm{~km}$ dari Kota Lahat. Data yang diperoleh dari lokasi penelitian merupakan data hasil uji laboratorium batubara melalui analisis proksimat, sehingga diperoleh variabelvariabel penentu kualitas batubara, berupa volatile matter (\%), fixed carbon (\%), ash content (\%), calorific value (cal/gr), dan total sulphur (\%). Dalam penelitian ini dipilih salah satu faktor yang sangat berpengaruh terhadap kualitas batubara, yaitu fixed carbon. Estimasi fixed carbon dilakukan dengan menggunakan Metoda Ordinary Point Kriging. Tabel 1 memperlihatkan data fixed carbon dalam satuan \% yang tersebar di 31 lokasi lubang bor dalam bidang 2 dimensi dengan koordinat $x$ dan $y$ dalam satuan meter. Untuk mengetahui ringkasan data tersebut digunakan fungsi >summary(data) pada Program R, hasilnya diperoleh statistika deskriptif seperti yang disajikan pada Tabel 2.

Statistika deskriptif data kualitas batubara di lokasi penelitian berdasarkan kandungan minimum dari fixed carbon sebesar $43,20 \%$ dan maksimum sebesar $44,00 \%$ dengan rata-rata sebesar $43,46 \%$ serta rata-rata calorific value $6340 \mathrm{cal} / \mathrm{gr}$ menunjukkan bahwa batubara di daerah penelitian termasuk klasifikasi lignite sesuai dengan kriteria pada Gambar 3. Nilai koefisien variasi yang relatif kecil $(0,01)$ menunjukkan bahwa data tersebut relatif tidak bervariasi.

Nilai rata-rata Fixed Carbon selanjutnya digunakan sebagai batas ukur, jika ratarata hasil estimasi mendekati rata-rata data sampel maka hasil estimasi tersebut bersifat akurat.

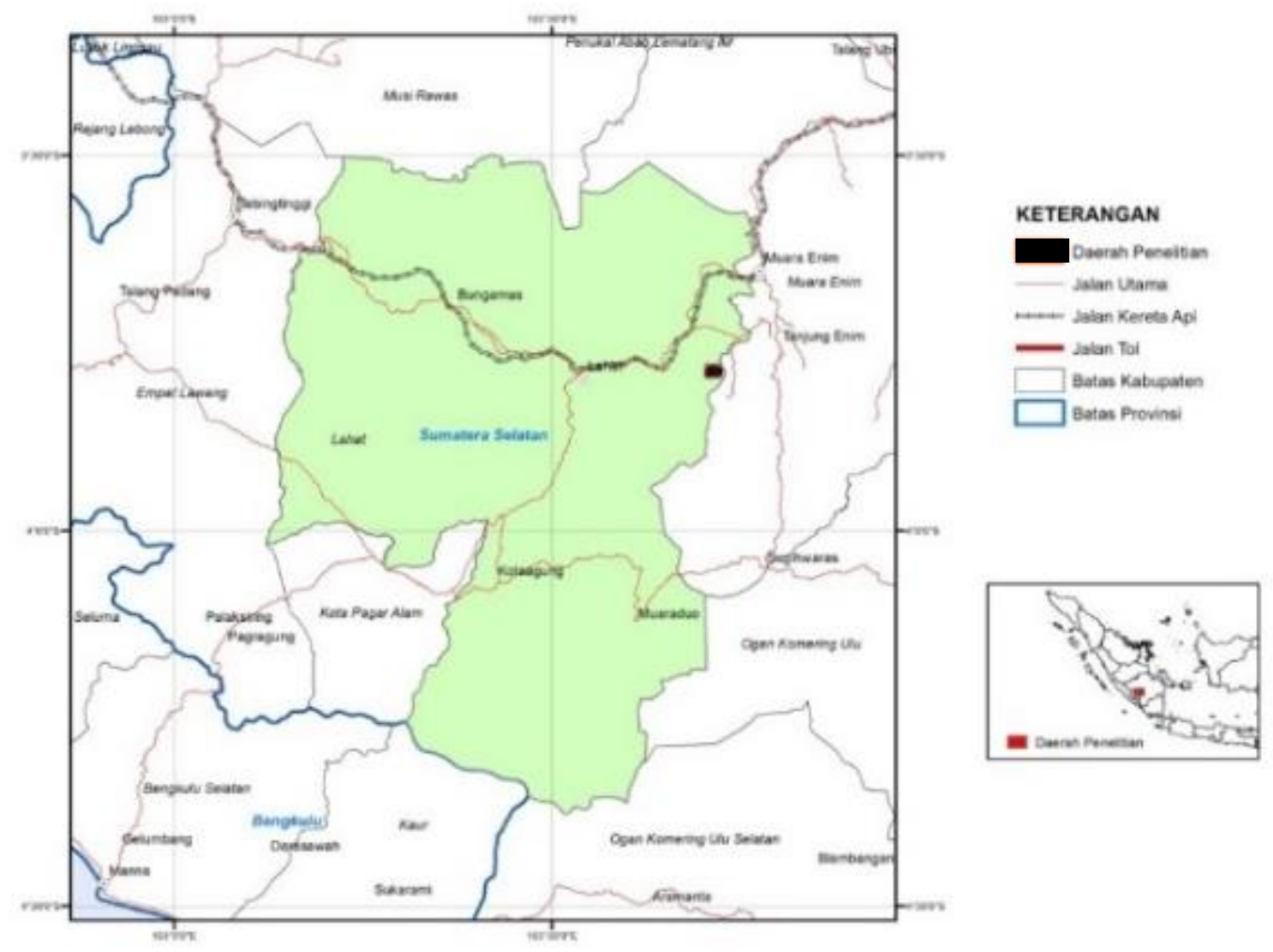

Gambar 4. Peta Lokasi Penelitian (Sumber: PT Bumi Merapi) 
Tabel 1. Data Fixed Carbon (\% adb) (Sumber: PT Bumi Merapi)

\begin{tabular}{lllll}
\hline Lokasi & Lubang Bor & $\boldsymbol{x}$ (meter) & $\boldsymbol{y}$ (meter) & \multicolumn{1}{c}{ Fixed Carbon (\%) } \\
\hline 1 & SR_01 & 350064.6 & 9579122 & 42.8 \\
\hline 2 & SR_02 & 349636.2 & 9578921 & 42.5 \\
\hline 3 & SR_03 & 349118.7 & 9578758 & 42.9 \\
\hline 4 & SR_04 & 348663.5 & 9578788 & 43.9 \\
\hline 5 & SR_05 & 348053.6 & 9579045 & 43.5 \\
\hline$\ldots$ & $\ldots$ & $\ldots$ & $\ldots$ & $\ldots$ \\
\hline 27 & SR_27 & 345990.5 & 9579857 & 44.2 \\
\hline 28 & SR_28 & 347376.8 & 9579781 & 42.9 \\
\hline 39 & SR_29 & 348982.8 & 9578847 & 44.2 \\
\hline 30 & SR_30 & 349854.5 & 9579416 & 42.7 \\
\hline
\end{tabular}

Tabel 2. Statistika Deskriptif Data Fixed Carbon

\begin{tabular}{cc}
\hline Statistics Descriptive & Fixed Carbon (\%) \\
\hline Minimum & 43,20 \\
\hline $1^{\text {st }}$ Quartil & 43,43 \\
\hline Median & 43,46 \\
\hline Mean & $\mathbf{4 3 , 4 6}$ \\
\hline $3^{\text {rd }}$ Quartil & 43,48 \\
\hline Maximum & 44,00 \\
\hline Variansi & 0,3396989 \\
\hline Koef. Variansi & 0,01341088 \\
\hline
\end{tabular}

Berdasarkan Tabel 1 dibuat plot sebaran data fixed carbon pada 31 lokasi lubang bor terhadap lokasi koordinat $x$ dan $y$ seperti disajikan pada Gambar 5.

Untuk estimasi nilai fixed carbon di lokasi tidak tersampel menggunakan Metoda Ordinary Point Kriging diperlukan analisis struktural yang merupakan sebuah proses pencocokan semivariogram eksperimental dengan semivariogram teoretis. Nilai semivariogram eksperimental dihitung berdasarkan semua pasangan jarak yang mungkin dimana fungsi jarak yang digunakan adalah jarak Euclidean, sehingga diperoleh hasil seperti pada Tabel 3 dan membentuk plot semivariogram eksperimental yang ditunjukkan pada Gambar 6.

Tabel 3 di atas memperlihatkan bahwa pasangan data yang terbanyak adalah pasangan data yang memiliki jarak ratarata sekitar 997,1352 $\mathrm{m}$ yang artinya bahwa kebanyakan titik-titik di lokasi tersampel yang menyebar pada tambang batubara memiliki jarak tersebut. Selanjutnya diperoleh plot rata-rata dari nilai semivariogram terhadap jaraknya dimana semua informasi disintesa dalam satu titik per kelas jarak. Kemudian dapat dilakukan fitting model semivariogram eksperimental dengan semivariogram teoretisnya.

Berdasarkan Gambar 6 plot semivariogram eksperimental dijadikan sebagai grafik acuan untuk menentukan model semivariogram teoretis yang terbaik dan paling sesuai dengan plot semivariogram eksperimental. Model semivariogram teoretis yang biasa digunakan para ahli Geostatistika diantaranya Model Eksponensial, Model Gaussian, dan Model Spherical. Proses perhitungan untuk memperoleh model teoretis yang terbaik dengan menggunakan input nilai, sill, dan range. Nilai sill sama dengan nilai variansi dari data sampel, sedangkan range merupakan hasil trial and error untuk memperoleh model teoretis terbaik dengan nilai Sum Square Error (SSE) yang paling minimum. Berdasarkan hasil uji coba diperoleh nilai range sebesar $700 \mathrm{~m}$ yang menghasilkan model teoretis dengan SSE paling minimum yang dipilih dari ketiga model semivariogram seperti pada Gambar 7 sampai Gambar 9. 


\section{MAKALAH ILMIAH}

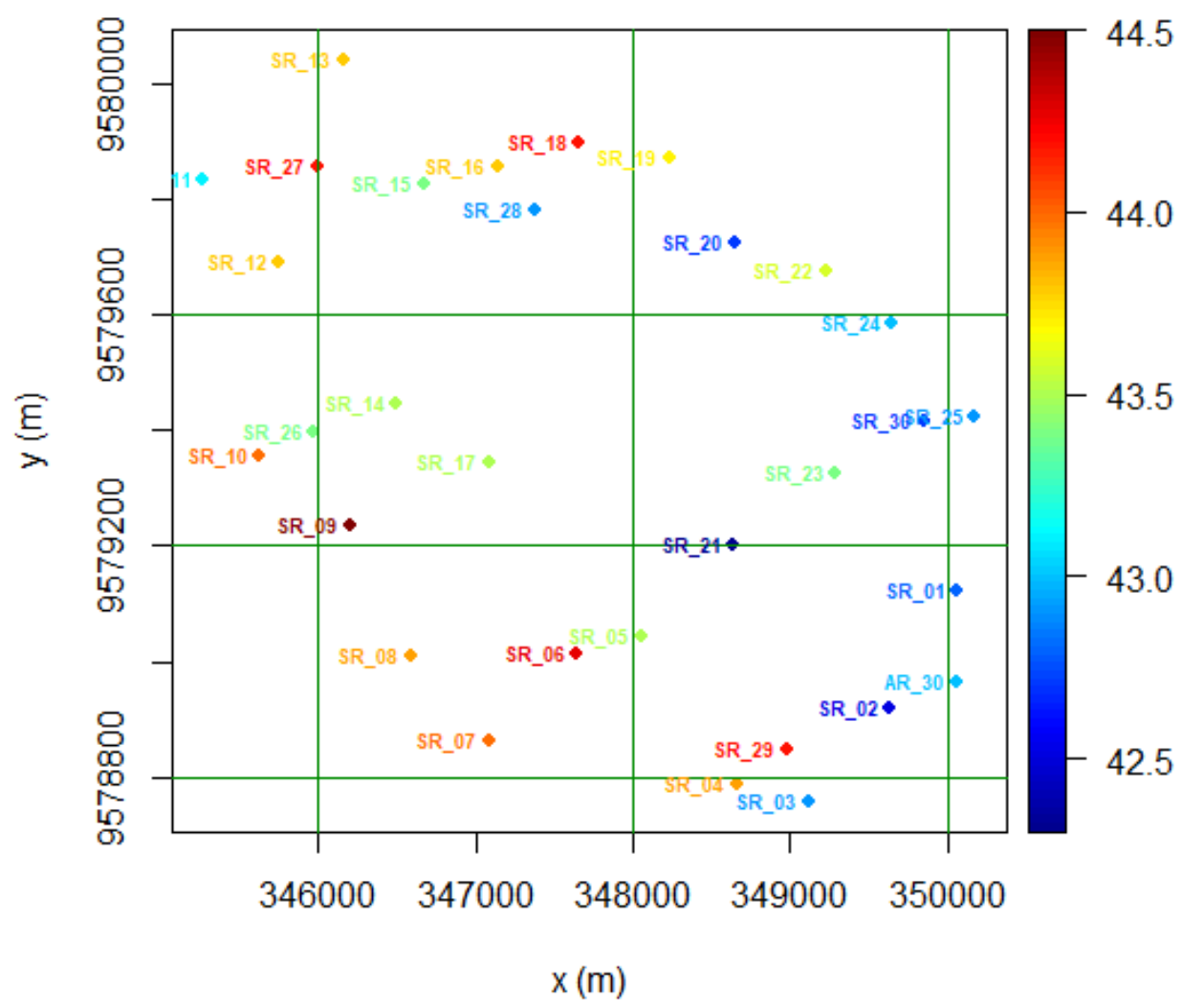

Gambar 5. Plot Sebaran Data Fixed Carbon

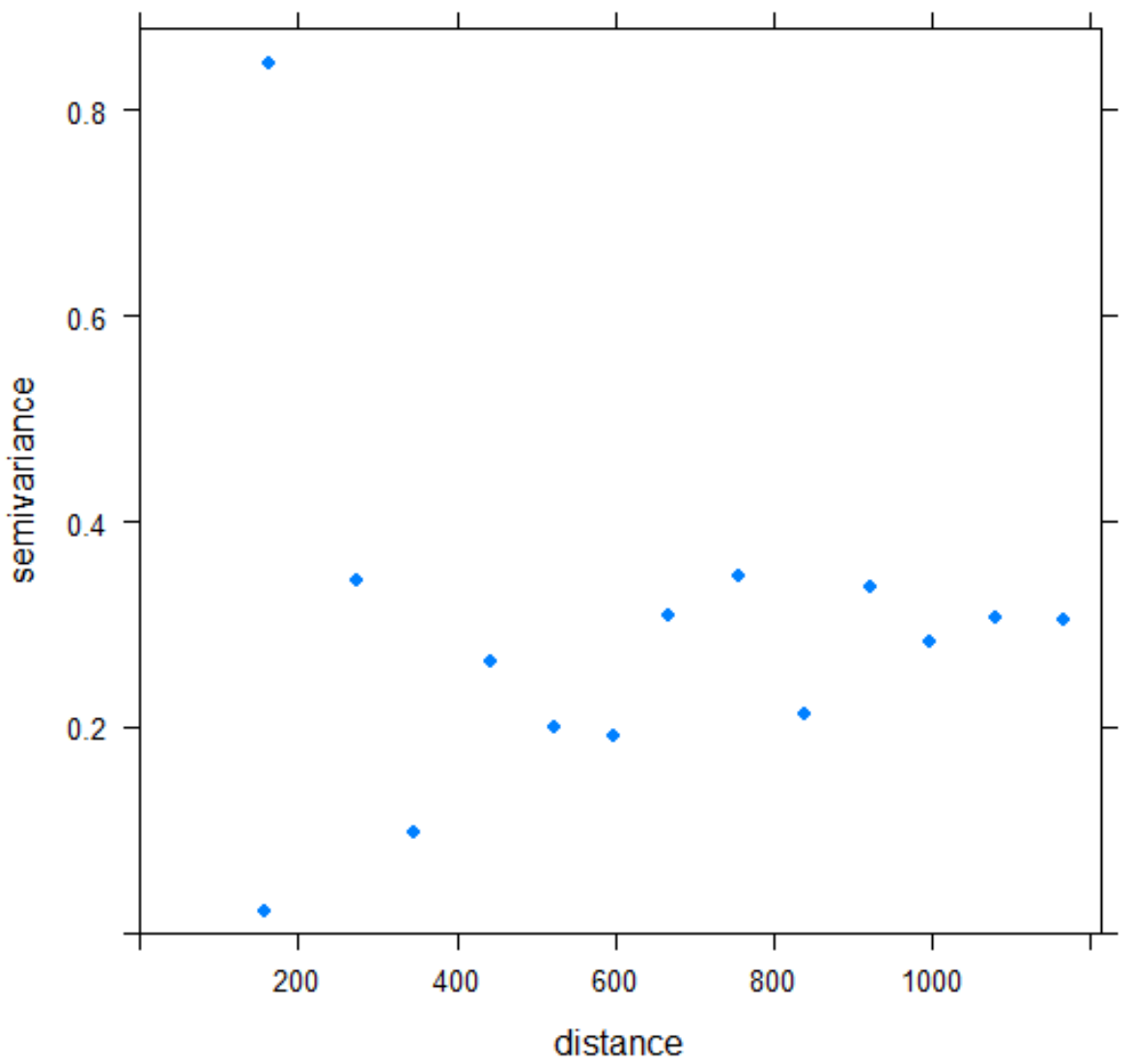

Gambar 6. Plot Semivariogram Eksperimental Data Fixed carbon 


\section{MAKALAH ILMIAH}

Tabel 3. Nilai Semivariogram Eksperimental

\begin{tabular}{cccc}
\hline No & $\begin{array}{c}\text { Banyaknya pasangan data } \\
\text { yang berjarak sama }\end{array}$ & $\begin{array}{c}\text { Jarak } \\
(\boldsymbol{m})\end{array}$ & $\begin{array}{c}\text { Nilai Semivariogram } \\
\text { Eksperimental }\end{array}$ \\
\hline 1 & 1 & 158,0729 & 0,0200 \\
\hline 2 & 1 & 162,4494 & 0,8450 \\
\hline 3 & 6 & 272,6208 & 0,3433 \\
\hline 4 & 9 & 346,8611 & 0,0972 \\
\hline 5 & 14 & 443,0466 & 0,2643 \\
\hline 6 & 16 & 523,3654 & 0,2003 \\
\hline 7 & 15 & 597,9616 & 0,1923 \\
\hline 8 & 13 & 667,4613 & 0,3092 \\
\hline 9 & 11 & 756,7730 & 0,3473 \\
\hline 10 & 15 & 838,7399 & 0,2117 \\
\hline 11 & 12 & 920,6316 & 0,3363 \\
\hline 12 & 25 & 997,1352 & 0,2820 \\
\hline 13 & 18 & 1080,09 & 0,3064 \\
\hline 14 & 8 & 1165,526 & 0,3050 \\
\hline
\end{tabular}

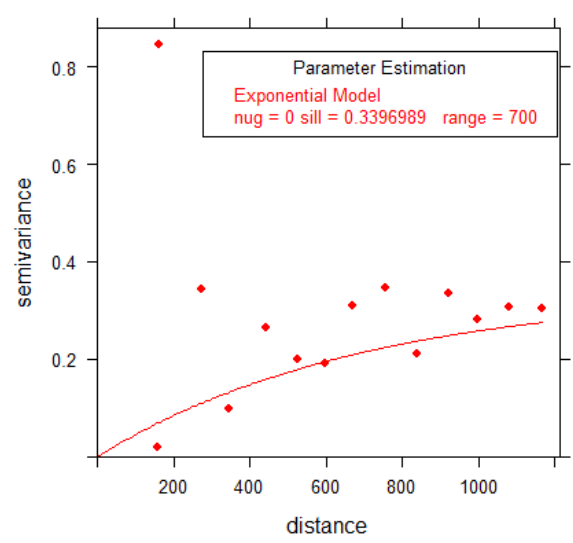

Gambar 7. Model Eksponensial

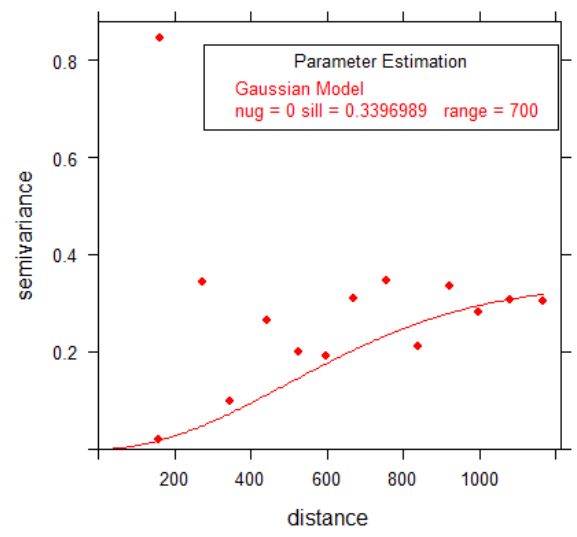

Gambar 8. Model Gaussian

Berdasarkan hasil fitting ketiga model semivariogram teoretis secara kasat mata dapat dilihat bahwa Model Gaussian yang paling cocok dengan plot semivariogram eksperimental. Untuk memperoleh perhitungan yang lebih akurat dihitung SSE dari ketiga model tersebut pada Tabel 4.

Berdasarkan Tabel 4 dapat dilihat bahwa dari ketiga model semivariogram teoretis yang memiliki SSE paling minimum adalah Model Gaussian sama seperti hasil fitting berdasarkan grafik, sehingga dapat disimpulkan bahwa parameter model semivariogram terbaik digunakan sebagai input pada perhitungan estimasi dengan Metoda Ordinary Kriging adalah parameter sill dan range Model Gaussian; sedangkan untuk 120 posisi lokasi tidak tersampel berikut koordinatnya diperoleh hasil seperti yang disajikan pada Tabel 5 .

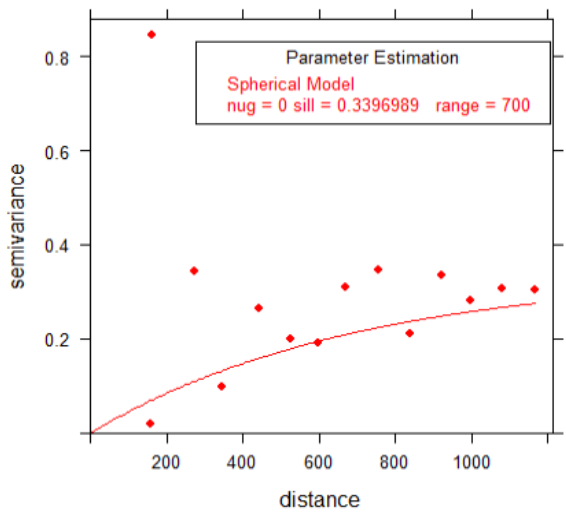

Gambar 9. Model Spherical

Tabel 4. SSE Model

Semivariogram Teoretis

SSE

\begin{tabular}{ccc}
\hline Eksponensial & Gaussian & Spherical \\
\hline 0,00033 & $\mathbf{0 , 0 0 0 1 6 0}$ & 0,000191 \\
\hline
\end{tabular}


Tabel 5. Estimasi di Lokasi Tidak Tersampel

\begin{tabular}{rrrr}
\hline Lokasi & \multicolumn{2}{c}{ Koordinat } & Estimasi (\%) \\
\hline 1 & $(349425$, & $9579763)$ & 43,00135 \\
\hline 2 & $(349426$, & $9579764)$ & 43,00086 \\
\hline 3 & $(350063$, & $9578921)$ & 43,06954 \\
\hline 4 & $(350065$, & $9579123)$ & 43,01693 \\
\hline 5 & $(349212$, & $9578992)$ & 43,25032 \\
\hline 6 & $(349213$, & $9578993)$ & 43,24983 \\
\hline 7 & $(349635$, & $9578920)$ & 43,17007 \\
\hline 8 & $(349637$, & $9578922)$ & 43,16908 \\
\hline 9 & $(349468$, & $9579543)$ & 43,04818 \\
\hline 10 & $(349469$, & $9579544)$ & 43,04769 \\
\hline 11 & $(349117$, & $9578757)$ & 43,33318 \\
\hline 12 & $(349119$, & $9578759)$ & 43,3322 \\
\hline 13 & $(349530$, & $9579917)$ & 42,93701 \\
\hline 14 & $(349531$, & $9579918)$ & 42,93651 \\
\hline 15 & $(348662$, & $9578787)$ & 43,43144 \\
\hline 16 & $(348664$, & $9578789)$ & 43,43046 \\
\hline 17 & $(347899$, & $9579850)$ & 43,33362 \\
\hline 18 & $(347900$, & $9579851)$ & 43,33313 \\
\hline 19 & $(348052$, & $9579044)$ & 43,50669 \\
\hline 20 & $(348054$, & $9579046)$ & 43,50571 \\
\hline 21 & $(348738$, & $9579978)$ & 43,10585 \\
\hline 22 & $(348739$, & $9579979)$ & 43,10535 \\
\hline 23 & $(347644$, & $9579011)$ & 43,60968 \\
\hline 24 & $(347646$, & $9579013)$ & 43,6087 \\
\hline 25 & $(348216$, & $9579113)$ & 43,45083 \\
\hline 26 & $(348217$, & $9579114)$ & 43,45033 \\
\hline 27 & $(347088$, & $9578861)$ & 43,77682 \\
\hline 28 & $(347090$, & $9578863)$ & 43,77585 \\
\hline 29 & $(347277$, & $9579502)$ & 43,56741 \\
\hline 30 & $(347278$, & $9579503)$ & 43,56692 \\
\hline 31 & $(346588$, & $9579010)$ & 43,85333 \\
\hline 32 & $(346590$, & $9579012)$ & 43,85235 \\
\hline 33 & $(345591$, & $9579511)$ & 43,95189 \\
\hline 34 & $(345592$, & $9579512)$ & 43,9514 \\
\hline 35 & $(346197$, & $9579234)$ & 43,88506 \\
\hline 36 & $(346199$, & $9579236)$ & 43,88408 \\
\hline 37 & $(346666$, & $9579995)$ & 43,58035 \\
\hline 38 & $(346667$, & $9579996)$ & 43,57986 \\
\hline 39 & $(345624$, & $9579355)$ & 43,98478 \\
\hline 40 & $(345626$, & $9579357)$ & 43,9838 \\
\hline 41 & $(349061$, & $9578790)$ & 43,33772 \\
\hline 42 & $(349062$, & $9578791)$ & 43,33723 \\
\hline 43 & $(345268$, & $9579833)$ & 43,94205 \\
\hline 44 & $(345271$, & $9579835)$ & 43,94085 \\
\hline 45 & $(346262$, & $9579964)$ & 43,68106 \\
\hline 46 & $(346263$, & $9579965)$ & 43,68057 \\
\hline 47 & $(345753$, & $9579688)$ & 43,86903 \\
\hline 49 & $(345755$, & $9579690)$ & 43,86806 \\
\hline 50 & $(348799$, & $9579707)$ & 43,16176 \\
\hline & & & 43,15895 \\
\hline
\end{tabular}




\begin{tabular}{rccr}
\hline Lokasi & Koordinat & Estimasi (\%) \\
\hline 51 & $(346160$, & $9580039)$ & 43,68498 \\
\hline 52 & $(346162$, & $9580041)$ & 43,684 \\
\hline 53 & $(345554$, & $9579865)$ & 43,86858 \\
\hline 54 & $(345555$, & $9579866)$ & 43,86809 \\
\hline 55 & $(346501$, & $9579443)$ & 43,76123 \\
\hline 56 & $(346502$, & $9579444)$ & 43,76074 \\
\hline 57 & $(349323$, & $9579534)$ & 43,08437 \\
\hline 58 & $(349324$, & $9579535)$ & 43,08388 \\
\hline 59 & $(346673$, & $9579825)$ & 43,62279 \\
\hline 60 & $(346675$, & $9579827)$ & 43,62181 \\
\hline 61 & $(345511$, & $9579481)$ & 43,97792 \\
\hline 62 & $(345512$, & $9579482)$ & 43,97743 \\
\hline 63 & $(347142$, & $9579856)$ & 43,50686 \\
\hline 64 & $(347144$, & $9579858)$ & 43,50588 \\
\hline 65 & $(347177$, & $9579459)$ & 43,60159 \\
\hline 66 & $(347178$, & $9579460)$ & 43,6011 \\
\hline 67 & $(347088$, & $9579343)$ & 43,65212 \\
\hline 68 & $(347090$, & $9579345)$ & 43,65115 \\
\hline 69 & $(348957$, & $9579639)$ & 43,14257 \\
\hline 70 & $(348958$, & $9579640)$ & 43,14207 \\
\hline 71 & $(347661$, & $9579896)$ & 43,37675 \\
\hline 72 & $(347663$, & $9579898)$ & 43,37577 \\
\hline 73 & $(348276$, & $9579502)$ & 43,33631 \\
\hline 74 & $(348277$, & $9579503)$ & 43,33582 \\
\hline 75 & $(348236$, & $9579871)$ & 43,25011 \\
\hline 76 & $(348238$, & $9579873)$ & 43,24913 \\
\hline 77 & $(349780$, & $9578997)$ & 43,11625 \\
\hline 78 & $(349781$, & $9578998)$ & 43,11575 \\
\hline 79 & $(348646$, & $9579723)$ & 43,19321 \\
\hline 80 & $(348648$, & $9579724)$ & 43,19249 \\
\hline 81 & $(350056$, & $9579631)$ & 42,88784 \\
\hline 82 & $(350057$, & $9579632)$ & 42,88734 \\
\hline 83 & $(348638$, & $9579202)$ & 43,32979 \\
\hline 84 & $(348640$, & $9579203)$ & 43,32907 \\
\hline 85 & $(345737$, & $9579927)$ & 43,81073 \\
\hline 86 & $(345738$, & $9579928)$ & 43,81025 \\
\hline 87 & $(349229$, & $9579673)$ & 43,07037 \\
\hline 88 & $(349231$, & $9579675)$ & 43,06939 \\
\hline 89 & $(346541$, & $9578912)$ & 43,88948 \\
\hline 90 & $(346542$, & $9578913)$ & 43,88899 \\
\hline 91 & $(349287$, & $9579326)$ & 43,14653 \\
\hline 92 & $(349289$, & $9579328)$ & 43,14554 \\
\hline 93 & $(346901$, & $9579824)$ & 43,57063 \\
\hline 94 & $(346902$, & $9579825)$ & 43,57014 \\
\hline 95 & $(349647$, & $9579582)$ & 42,99626 \\
\hline 96 & $(349649$, & $9579584)$ & 42,99527 \\
\hline 97 & $(345976$, & $9579987)$ & 43,74056 \\
\hline 98 & $(345977$, & $9579988)$ & 43,74007 \\
\hline 99 & $(350175$, & $9579422)$ & 42,91392 \\
\hline 100 & $(350177$, & $9579424)$ & 42,91293 \\
\hline & $(349747$, & $9578858)$ & 43,15986 \\
\hline & & & \\
\hline
\end{tabular}




\begin{tabular}{rrrr}
\hline Lokasi & \multicolumn{2}{c}{ Koordinat } & Estimasi (\%) \\
\hline 102 & $(349748$, & $9578859)$ & 43,15936 \\
\hline 103 & $(345974$, & $9579394)$ & 43,89468 \\
\hline 104 & $(345975$, & $9579396)$ & 43,89394 \\
\hline 105 & $(347497$, & $9579183)$ & 43,59917 \\
\hline 106 & $(347498$, & $9579182)$ & 43,5992 \\
\hline 107 & $(345989$, & $9579856)$ & 43,77155 \\
\hline 108 & $(345991$, & $9579858)$ & 43,77057 \\
\hline 109 & $(346102$, & $9579485)$ & 43,84182 \\
\hline 110 & $(346103$, & $9579486)$ & 43,84133 \\
\hline 111 & $(347375$, & $9579780)$ & 43,47283 \\
\hline 112 & $(347377$, & $9579782)$ & 43,47185 \\
\hline 113 & $(348420$, & $9578789)$ & 43,4872 \\
\hline 114 & $(348421$, & $9578790)$ & 43,4867 \\
\hline 115 & $(348981$, & $9578846)$ & 43,34191 \\
\hline 116 & $(348983$, & $9578848)$ & 43,34093 \\
\hline 117 & $(346168$, & $9579856)$ & 43,73058 \\
\hline 118 & $(346169$, & $9579857)$ & 43,73009 \\
\hline 119 & $(349853$, & $9579415)$ & 42,9912 \\
\hline 120 & $(349855$, & $9579417)$ & 42,99021 \\
\hline
\end{tabular}

Tabel 6. Statistika Deskriptif Data Estimasi Fixed Carbon

\begin{tabular}{cc}
\hline Statistics Descriptive & Fixed Carbon (\%) \\
\hline Minimum & 42,89 \\
\hline 1st $^{\text {Quartil }}$ & 43,16 \\
\hline Median & 43,48 \\
\hline Mean & $\mathbf{4 3 , 4 6}$ \\
\hline $3^{\text {rd }}$ Quartil & 43,75 \\
\hline Maximum & 43,98 \\
\hline Variansi & 0,1039567 \\
\hline Koef. Variansi & 0,00741885 \\
\hline
\end{tabular}

Berdasarkan Tabel 5 diperoleh hasil estimasi Fixed Carbon pada 120 lokasi tidak tersampel dengan perhitungan menggunakan Metoda Ordinary Point Kriging dengan rata-rata hasil estimasi $43,46 \%$ yang nilainya sama dengan ratarata data sampel yang sebenarnya, yaitu di sekitar nilai 43,46\%. Kualitas Fixed Carbon yang kurang dari $60 \%$ ini menunjukkan bahwa klasifikasi batubara di lokasi penelitian merupakan rank Lignite. Koefisien variasi data estimasi di 120 lokasi tidak tersampel bernilai 0,007 menunjukkan data estimasi memiliki variasi cukup kecil, sehingga estimasi di 120 lokasi tidak tersampel juga mendukung hasil penelitian bahwa variabel tersebut merupakan Fixed Carbon. Secara keseluruhan hasil penerapan Metoda Ordinary Point Kriging menggunakan
Aplikasi R, dalam perhitungan estimasi nilai variabel di lokasi tidak tersampel dapat dilakukan dengan mudah dan cepat serta memberikan hasil yang akurat. Hal ini ditunjukkan dengan rata-rata nilai estimasi mendekati rata-rata nilai sebenarnya. Hasil estimasi variabel Fixed Carbon tersebut selanjutnya dipetakan berupa plot dalam nilai interval yang digambarkan berupa titiktitik dalam warna yang berbeda seperti disajikan pada Gambar 10. Hasil plot menunjukkan posisi lokasi yang memiliki estimasi dari interval terendah ke interval tertinggi, semakin ke kiri nilai estimasi semakin tinggi. Estimasi fixed carbon tersebut dapat digunakan sebagai rekomendasi bagi pengambil kebijakan dalam eksplorasi pertambangan batubara di suatu wilayah berdasarkan kajian Geostatistika menggunakan Aplikasi R. 


\section{MAKALAH ILMIAH}

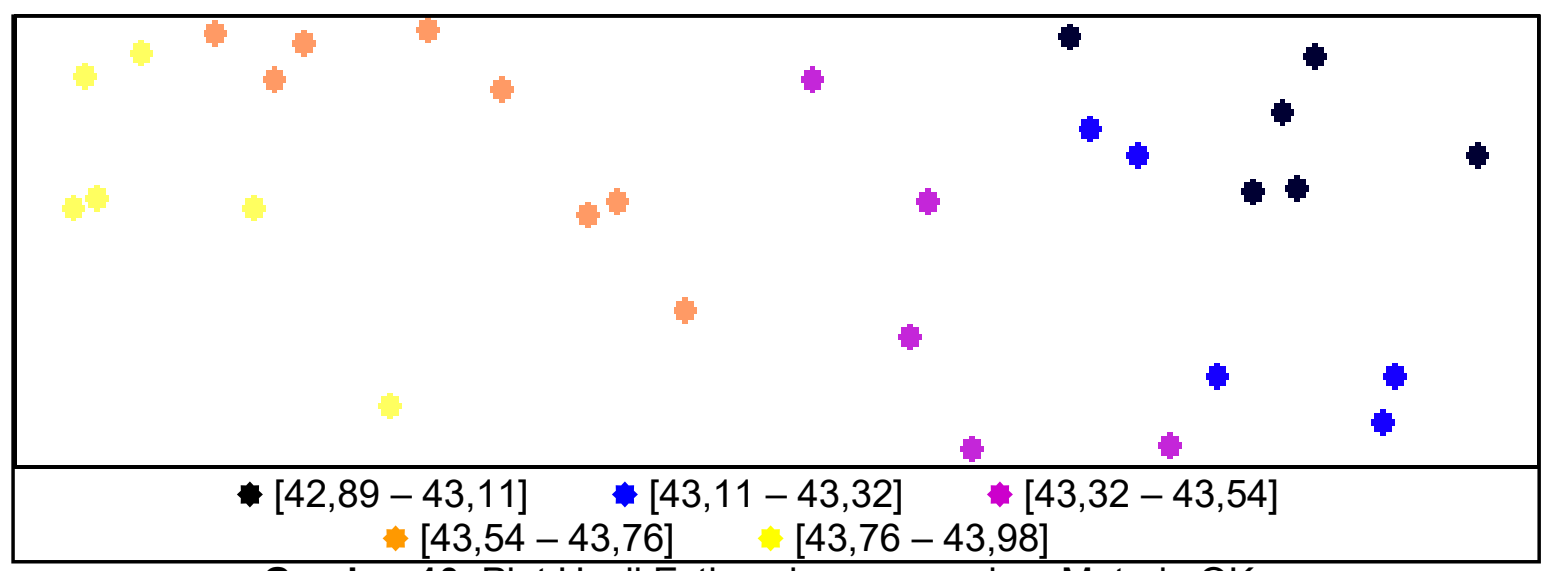

Gambar 10. Plot Hasil Estimasi menggunakan Metoda OK

\section{KESIMPULAN}

Estimasi fixed carbon sebagai variabel dalam kualitas batubara dengan Metoda Ordinary Point Kriging di 120 lokasi tidak tersampel memberikan nilai rata-rata mendekati rata-rata data sampel. Hal ini menunjukkan bahwa Metoda Ordinary Point Kriging tepat digunakan untuk mengestimasi nilai observasi di lokasi tidak tersampel secara teoritis. Hasil penerapan pada data lapangan dengan bantuan package gstat pada Aplikasi R memberikan perhitungan yang lebih cepat, lebih mudah dan akurat.

\section{UCAPAN TERIMA KASIH}

Penulis mengucapkan terima kasih kepada Rektor Universitas Padjadjaran yang telah mendanai penelitian ini melalui Academic Leadership Grant (ALG) dan RKDU 2018/2019 serta kepada reviewer atas masukan dan saran yang sangat berharga dalam penyempurnaan paper ini.

\section{DAFTAR PUSTAKA}

Arisandy, A. A., Nugroho, W., Winaswangusti A. U. (2017). Peningkatan Kualitas Batubara Sub Bituminous Menggunakan Minyak Residu Di PT X Samarinda, Kalimantan Timur. Jurnal Teknologi Mineral FT UNMUL, 5 (1), 1-6.
Bivand, R. S., Pebesma, E., \& Rubio, V. G. (2013). Applied Spatial Data Analysis with $R$ Second Edition. New York: Springer.

Cressie, N. A. (1993). Statistics For Spatial Data. New York: John Wiley \& Sons, Inc.

Ertunc, G., Tercan, A. E., Hindistan, M. A., Unver, B., Unal, S., Atalay, F., \& Killioglu, S. Y. (2013). Geostatistical estimation of coal quality variables by using covariance matching constrained kriging. International of Coal Geology, 112, 1422,http://dx.doi.org/10.1016/j.coal.20 12.11.014.

Falah, A. N., Abdullah, A. S., Parmikanti, K., \& Ruchjana, B. N. (2017a). Prediction of Cadmium Pollutant With Ordinary Point Kriging Method Using GStat-R. AIP Conference Proceedings: The 2nd International Conference on Applied Statistics (ICAS II 2016), 1827, 020019 https://doi.org/10.1063/1.4979435.

Falah, A. N., Subartini, B., \& Ruchjana, B. N. (2017b). Application of universal kriging for prediction pollutant using GStat R. IOP Conf. Series: Journal of Physics: Conf. Series , 893, doi :10.1088/1742-6596/893/1/012022, 1-7. 
Gunawan, A. A., Falah, A. N., Faruk, A., Lutero, D. S., Ruchjana, B. N., \& Abdullah, A. S. (2016). Spatial Data Mining for Predicting of Unobserved Zinc Pollutant using Ordinary Point Kriging. IEEE: International Workshop on Big Data and Information Security 978-1-50903477-2/16/\$31.00 83-88.

Hamid, N. (2017). Distribusi Kuat Geser Batuan pada Formasi Muara Enim di Kecamatan Merapi Barat, Kabupaten Lahat, Provinsi Sumatera Selatan Menggunakan Metoda Kriging, Disertasi, Tidak Diterbitkan. Bandung: Aplikasi Pascasarjana Fakultas Teknik Geologi Universitas Padjadjaran.

Olea, R. A. (1999). Geostatistics for engineers and earth scientists. New York: Kluwer Academic Publishers.

Ruchjana, B. N., Abdullah, A. S., \& Falah, A. N. (2017). Penerapan Aplikasi GStat Berbasis $R$ untuk Geostatistika dengan Pendekatan Spasial Data Mining. ISBN 602640827-4 Jatinangor: ALQAPRINT.
Schweinfurth, S. P. (2009). An Introduction to Coal Quality. Virginia.

Srivastava, R. M. (2013). Geostatistics: A toolkit for data analysis, spatial prediction and risk management in the coal industry. International Journal of Coal Geology , 112, 2-13, http://dx.doi.org/10.1016/j.coal.2013. 01.011.

Varberg, D., Purcell, E., \& Rigdon, S. (2007). Calculus Ninth Edition. Pearson Education, Inc.

Wackernagel, H. (1994). Cokriging versus kriging in regionalized multivariate data analysis. Elsevier Science B. V., 83-92.

Youkuo, C., Yongguo, Y., \& Wangwen, W. (2015). Coal Seam Thickness Prediction based on Least Squares Support Vector Machines and Kriging Method. EJGE, 20 Bund. 1 167-176.

https://www.geologinesia.com/2016/01/ tempat-dan-proses-pembentukanbatubara. html

https://www.cnbcindonesia.com/news/201 90624120905-4-80160/cadanganbatu-bara-ri-naik-jadi-3989-miliar-ton

\begin{tabular}{|ll|}
\hline Diterima & $:$ 19 Februari 2019 \\
Direvisi & $:$ 08 Juni 2019 \\
Disetujui & $:$ 30 Agustus 2019 \\
\hline
\end{tabular}

